\title{
Traditional Game-Based Physical Exercise for Disabled Children
}

\author{
Boyke Mulyana*, Sandey Tantra Paramitha \\ Faculty of Sport and Health Science Education \\ Universitas Pendidikan Indonesia \\ Bandung, Indonesia \\ *boyke.mulyana@yahoo.com, sandeytantra18@upi.edu
}

\author{
I Wayan Repiyasa, Gede Angga Andika, Filardi \\ Anindito, Azry Ayu Nabillah, Desy Tya Maya Ningrum, \\ Muhtar Asshagab \\ Graduate program \\ Universitas Negeri Jakarta \\ Jakarta, Indonesia
}

\begin{abstract}
This study aims to produce a product in the form of a physical condition training model based on traditional games for children with disabilities. This study uses the method of Borg and Gall which consists of ten steps. The research subjects were children with disabilities at the SLB B Bali School. A total of 3 models and 15 variations of the model were carried out and through several levels of testing and revision. The results of the pre test and posts test were obtained with. Paired Sample T-test with a significance level of 0.05 . Pre test and posts test $1 / 2 \alpha$ $(0,0026)>1 / 2$ Sig. (2-tailed) $(0,000)(0.05$ significance level), zero hypothesis rejected. concluded, there are significant differences between the pre test and posts test on the results of physical fitness test, and for affective results $1 / 2 \alpha(0.005)>1 / 2$ Sig. (2-tailed) $(0,000)(0.05$ significance level), zero hypothesis rejected. It was concluded, there were significant differences between the pre test and posts test on the physical fitness affective test results, concluded that physical condition training based on traditional games on disabled children was effectively used to improve children's physical fitness.
\end{abstract}

Keywords: children with disabilities, model of exercise, physical fitness, traditional games

\section{INTRODUCTION}

Traditional games are part of Indonesian children, this game is called folk games which are legendary and every game has a story or history contained in it. This traditional game can also teach many things to children, the content contained in this game can train children in good character and physical fitness. Generally, traditional games have regional characteristics that are in accordance with local cultural traditions in accordance with the customs of the area [1]. Traditional games have an element of sportsmanship, honesty, precision, agility, accuracy in determining steps, and working in groups [2]. Many benefits can be obtained from traditional Indonesian games that must be taught to children and all circles that still exist.

Indonesia has a variety of traditional games, all regions and provinces have their own regional games, including traditional Balinese games. A variety of traditional games on the island of Bali, among others, megala-gala, mengeb-crunching, mesiap, ready to go goakan, metajog and the like [3]. These games are often found but only to fill certain days. The problems faced today are rarely taught and developed the values of traditional games and the erosion of the value of this traditional game by modern games that are separated from the control of parents and schools.

This traditional game should be able to be played by all people from both children, adolescents and adults, not to mention also for children with disabilities. Disabled children are currently free from attention, this traditional game can also be taught and trained for disabled children, and this is because children with disabilities are also part of Indonesian children. Traditional games have many benefits and can be played by all groups [4]. Therefore, children with disabilities cannot play traditional games to maintain their physical condition. The results of preliminary observations through observation and interviews with several teachers in disability schools teaching model materials implemented for children with disabilities using traditional games are still rarely taught. The results of these authors are very motivated to make physical condition exercises based on traditional games for children with disabilities so that children with disabilities are able to learn the culture of the archipelago. The purpose of this study is: to produce traditional game-based physical condition exercises for children with disabilities in SLB B Bali.

Physical conditions that must be owned by all people, physical condition is the main requirement to trigger daily activities. Physical condition is the capacity of a person to perform physical work with multilevel abilities [5]. The exercise model is a series of components - a training strategy component that is integrated in several components. Disability for children is carried out and directed in coaching in order to achieve physical conditions that are in accordance with the goals [6]. The direction of physical conditions is needed by children with disabilities for daily children's activities. Physical condition is physical movement activity carried out to improve physical fitness for optimal physical work ability [7].

Seeing from the experts' explanation that physical conditions are very important for children in general and especially for children with disabilities due to children with disabilities to carry out daily activities and support movement body. 
- $H_{i}: \mu_{2}>\mu_{1}$ There was a significant increase in physical fitness test results before and after receiving a traditional physical exercise based model.

This research is research \& development ( R \& D) research through the method according to Board and gall [8]. The study was conducted by collecting qualitative and quantitative data through 10 steps of research [9].

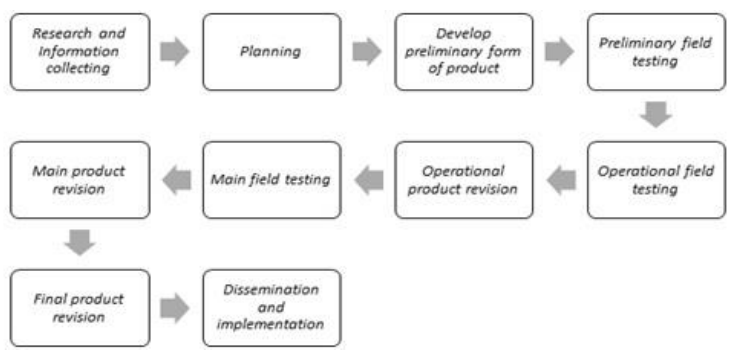

Fig. 1. Steps of research.

This study took place at Jimbaran Bali B SLB for physically disabled children. The types of data collected at this stage of the research are qualitative and qualitative data. In this study the data collection technique was the development of the results of the pre test and posts test to obtain data on the physical condition training model based on traditional games. Data Analysis Techniques The analytical techniques used in the research were descriptive percentage analysis techniques. To analyses the results of data collection from expert reviews and the data obtained are qualitative data as well as the T. Test.

\section{RESULTS AND DISCUSSION}

Traditional games are generally only done for folk games and children's games in the 90s [10]. This game began to be rarely played after entering in the 2000s. This game has many benefits and can be developed to train one of the physical conditions for children with disabilities [11-13]. Seeing this In general, the results of this study are in the form of physical condition training models and manuals for the physical condition training model based on traditional games for children with disabilities $[4,14,15]$. Two trials were carried out, namely small group field tests and large group field trials. the last new effectiveness test. In this study after going through a trial it produced 10 traditional games for children with disabilities. This research was conducted in 12 activities. The results of this study are described in the following table:

TABLE I. PAIRED SAMPLE T-TEST

\begin{tabular}{|c|c|c|c|c|c|c|c|c|}
\hline & \multicolumn{5}{|c|}{ Paired Differences } & \multirow[t]{3}{*}{$\mathbf{t}$} & \multirow[t]{3}{*}{ df } & \multirow{3}{*}{$\begin{array}{l}\text { Sig. } \\
(2- \\
\text { tail } \\
\text { ed) }\end{array}$} \\
\hline & \multirow[t]{2}{*}{ Mean } & \multirow[t]{2}{*}{$\begin{array}{c}\text { Std. } \\
\text { Deviatio } \\
n\end{array}$} & \multirow[t]{2}{*}{$\begin{array}{l}\text { Std. } \\
\text { Error } \\
\text { Mean }\end{array}$} & \multicolumn{2}{|c|}{$\begin{array}{c}95 \% \\
\text { Confidence } \\
\text { Interval of the } \\
\text { Difference } \\
\end{array}$} & & & \\
\hline & & & & Lower & Upper & & & \\
\hline $\begin{array}{l}\text { Pretest - } \\
\text { Posttest }\end{array}$ & -3.015 & 1.949 & .240 & -3.494 & -2.536 & $\begin{array}{l}- \\
12.5 \\
66\end{array}$ & 60 & .000 \\
\hline
\end{tabular}

Hypothesis of Statistical:

- $H_{0}: \mu_{2}=\mu_{1}$ There was no significant increase in the results of the physical fitness test before and after receiving the traditional physical exercise based model.
- $\alpha=0,05$

- $\quad$ Sig. $(2$-tailed $)=0.000$

- $H_{0}$ accepted if $\alpha \leq 1 / 2$ Sig. (2-tailed), decision: because of value $1 / 2 \alpha(0,0025)>1 / 2 \mathrm{Sig}$. (2-tailed) $(0,000)$ then $H_{0}$ rejected, that there was a significant increase in the results of the physical fitness test before and after receiving the traditional game-based physical condition training model.

Looking at the data description above, there was a significant increase in students' physical fitness after treatment with a traditional physical exercise model for disabled children. Based on the trial activities that have been carried out it is necessary to revise the distance and time in the game, instructions in the game. Revisions made to variations made in traditional games adjust to the needs of children with disabilities so the game is not difficult to play.

The products in this study are to increase the variety of physical condition exercises for children with disabilities and maintain traditional sports in children. The subjects in the study were SLB B schools that still did not use the methods and variations in the application of training. This gives the view that variations in training in traditional games can be done to add references and make children more active. This product after reviewing weaknesses, can be delivered several advantages, namely; provide a view of the benefits of traditional games. Maintain culture in local wisdom. Enrich the movement for students. Students become more active, happy and enthusiastic. Practical activities are more interesting. Simplify and add references to children with disabilities.

\section{CONCLUSIONS}

The results of the research on the physical condition training model based on traditional games for children with disabilities were seen from the data obtained through expert revisions and trials that the physical exercise model based on traditional games for disabled children in SLB B gave a very good physical condition of the child and when the child rejoiced when doing it. Based on the research stages, the physical condition training model based on traditional games on children with disabilities and from the results of revisions and trials of these products is effectively used and implemented in everyday life.

\section{REFERENCES}

[1] U. Hasanah, Pengembangan Kemampuan Fisik Motorik Melalui Permainan Tradisional Bagi Anak Usia Dini. 2016.

[2] M. Ridwan and M. Mas'odi, Tradisi Nyanyian Anak Terhadap Pembentukan Karakter Anak Usia Sekolah Dasar. Sekol. Dasar Kaji. Teor. dan Prakt. Pendidik, 2017.

[3] R. Nuriman, N. Kusmaedi and S. Yanto, "Pengaruh Permainan Olahraga Tradisional Bebentengan terhadap Kemampuan Kelincahan Anak Usia 8-9 Tahun,” J. Terap. Ilmu Keolahragaan, 2018. 
[11] D. Furió, M.C. Juan, I. Seguí, and R. Vivó, "Mobile learning vs. traditional classroom lessons: A comparative study,” J. Comput. Assist. Learn, 2015.

[12] J. Sareen, F. Jacobi, B.J. Cox, S.L. Belik, I. Clara, \& M.B. Stein, "Disability and poor quality of life associated with comorbid anxiety disorders and physical conditions," Archives of internal medicine, vol. 166(19), pp. 2109-2116, 2006.

[13] C.S. Dewa, E. Lin, M. Kooehoorn, \& E. Goldner, "Association of chronic work stress, psychiatric disorders, and chronic physical conditions with disability among workers," Psychiatric services, vol. 58(5), pp. 652-658, 2007.

[14] T.Y. Akhutina, N. Foreman, A. Krichevets, L. Matikka, V. Narhi, N. Pylaeva, \& J. Vahakuopus, "Improving spatial functioning in children with cerebral palsy using computerized and traditional game tasks, "Disability and rehabilitation, vol. 25(24), pp. 1361-1371, 2003.

[9] M..D. Gall, J.P. Gall, and W.R. Borg, Educational Research, 7th ed., Educational Research: An introduction, 2003.

[10] W. Zhang et al., "Type 1 diabetes therapeutic education in a non-profit association, T1Diams. An overview,” J. Med. Internet Res, 2015.

[15] T.D. Orlick, "Positive socialization via cooperative games," Developmental Psychology, vol. 17(4), pp. 426, 1981. 